\title{
scripted
}

Volume 11, Issue 3, December 2014

\section{EDITORIAL: DOING THE RIGHT THING?}

\author{
Karen Mc Cullagh, Daithí Mac Sithigh
}

DOI: $10.2966 /$ scrip.110314.206

\section{(c) (1) $\$ \odot$}

EY No ND (C) Karen Mc Cullagh and Daithí Mac Síthigh 2014. This work is licensed under a Creative Commons Licence. Please click on the link to read the terms and conditions.

* Dr Karen Mc Cullagh, Lecturer in Law, University of East Anglia, k.mccullagh@ uea.ac.uk; Dr Daithí Mac Síthigh, Reader in Law, Newcastle University, daithi.macsithigh@ncl.ac.uk. 
The 29th annual conference of the British \& Irish Law, Education and Technology Association (BILETA) ${ }^{1}$ was hosted by Dr Karen Mc Cullagh (co-editor of this special edition) at the University of East Anglia in the city of Norwich, 14-16th April 2014. Some of the best papers from the conference are brought together here in this special edition of SCRIPT-ed. ${ }^{2}$

Norwich was an apt location to host a conference that invited delegates to explore the legal challenges posed by technological developments. While its (sadly no longer Premier League) football team (co-owned by none other than Delia Smith) and Alan Partridge may be recognisable icons of the fine city, Norwich's commercial and industrial heritage extends back much further than many English cities, and its new University of the Arts and growing video game sector demonstrates the strength of the creative industries in the city and county.

The cover image for this edition of SCRIPTed is a 'blue plaque' erected in Norwich in April 2014. Such plaques often mark the former residence of a famous (dead) writer, or events of political significance. This particular memorial, however, marks an anniversary of some significance in technology and the State: the fortieth anniversary of the introduction of postcodes in the UK, and the particular role of Norwich in this project.

An ever-increasing volume of post, which was time-consuming to sort by hand, underpinned calls for technological innovation. In response, a decision was made to trial mechanised sorting in Norwich in 1959. This technical innovation proved successful and was rolled out across the UK in 1974 - with Norwich, the location of the pilot project, being the last area to be switched to the new system.

The history of the postal system is a story of competing versions of the public interest, and responses to technological convergence. In recent years, post has increasingly been supplemented or even in some cases replaced by email and social media applications. Thus, it was fitting that delegates submitted papers that examined whether existing laws target the 'right things' and provide adequate protection for rights, and if not, proposed solutions on the right thing to do.

Maria Murphy's paper was particularly timely (and relevant to the many academic researchers in attendance) since it addressed the benefits and risks posed by social media communication technologies (e.g. Twitter) that are increasingly employed by academics to communicate, disseminate ideas and engage in debate. Whilst the benefits of such technologies are readily apparent (e.g. new platforms to engage with

\footnotetext{
${ }^{1}$ www.bileta.ac.uk

${ }^{2}$ Other papers presented at the conference will appear in due course in the European Journal of Law and Technology and the International Review of Law, Computers \& Technology.
} 
fellow academics, students and the wider public), they can expose users to negative publicity and present reputational risk for both the academic and the insitution employing them. In response to these risks some academic institutions may be tempted to supervise the use of social media by their employees. This article evaluates the potential chilling efffect and threat to academic freedom posed by overly-zealous institutional oversight and calls for academic institutions to introduce protective social media policies that explicitly recognise the application of academic freedom in the social media context.

The transmission of assets generated in virtual worlds (e.g. World of Warcraft or Second Life) upon death was the focus of the paper presented by postgraduate researcher (and winner of the BILETA Best Postgraduate Paper prize) Edina Harbinja. She examined existing laws and reported that, at present, virtual assets are typically governed by contractual rights, and since contracts expressly exclude survivability, the transmission of virtual assets on death to surviving heirs is impossible. She explored and then argued against the recognition of "virtual property" as a concept and instead suggests a solution in the form of "VW usufruct"- a combination of virtual easement and intangible usufruct since would allow a player's personal representative/executor to gain access to the account and extract any possible monetary value before the virtual world account expires. Edina's paper also engaged with questions of Scots private law - reminding us that even while jurisdiction is challenged by some, an awareness of the diversity of legal traditions across Britain and Ireland is essential for organisations such as BILETA.

The societal expectation of personalised services and evidence-based decision-making means that personal information processing is at the heart of the information society. This is a question that Postmaster Generals of old would well understand. At the same time, the 'open data' initiative is prompting public sector departments to make their administrative data available in re-useable formats. However, it is not clear that there is widespread public support for data sharing either within public sector organisations or between private and public sector organisations. Thus, Marion Oswald's paper makes an important contribution to the debate, since it explores through an empirical study, whether UK citizens are supportive of the sharing of personal data for secondary uses. This is a timely study given the UK government's controversial proposal care.data to permit secondary reuse of patient's health data by both the public and private sectors. Her research confirms that necessity of public services does not result in a readiness by individuals to sacrifice their privacy and share their personal data. The public report high levels of concern regarding the sharing of their personal data with other organisations, and this suggests that the UK Government must do more to allay concerns that privacy is at risk when data is shared.

Copyright is a longstanding concern of BILETA, and unsurprisingly was the subject of many papers at this year's conference. We are pleased to publish Martina Gillen's contribution, examining the judgments of three recent CJEU decisions in the field of intellectual property: UsedSoft (C-458/13), PC Box (C-355/12) and Grund (C458/13). Her analysis examines the relationship between copyright and competition law in the context of software regulation cases and demonstrates that the CJEU drew 
upon ideas from competition law including the principle of specific subject matter and exercising an intellectual property in an abusive fashion. She posits that these cases are indicative of a piecemeal attempt to ameliorate the effects of copyright by strengthening the competition law aspects of the jurisprudence in interpreting copyright claims but concludes that a clearer, less complex statement of principle is required from the CJEU if it is to take copyright in this new direction.

The conference took placed at the recently renovated Grade II* listed building of the UEA Law School, Earlham Hall. Delegates also had the opportunity to visit the city centre, and the landmark Sainsbury Centre for Visual Arts (recently listed at Grade II*), also located on the UEA campus. Blending new and old, art and science, Norwich was a fitting venue for the wide range of contributions on law, education and technology heard within this year's BILETA conference. We hope that SCRIPTed readers enjoy this selection of papers. 